\title{
Are Elephants the Most Disastrous Agricultural Pests or the Agents of Ecological Restorations?
}

\section{Mamboleo AA*, Doscher C and Paterson A}

Department of Informatics and Enabling Technologies, Lincoln University, New Zealand

*Corresponding author: Abel Ansporthy Mamboleo, Department of Informatics and Enabling Technologies, Lincoln University, P O Box 85084, Postal Code 7647, Christchurch, New Zealand, Tel: +255769247990; E-mail: ebbo54@yahoo.com

Received date: March 11, 2017; Accepted date: March 25, 2017; Published date: March 30, 2017

Copyright: (c) 2017 Mamboleo AA, et al. This is an open-access article distributed under the terms of the Creative Commons Attribution License, which permits unrestricted use, distribution, and reproduction in any medium, provided the original author and source are credited.

\begin{abstract}
Human-elephant interactions occur in the areas where people coexist with elephants. It happens in the communities neighbouring core wildlife protected areas. Human and elephants have coexisted since the beginning of agriculture. The relationship between humans and elephants has deteriorated since humans have increased their dependence on domesticated herbivores and encroached into elephant habitats. The interactions usually result in human deaths, elephant deaths, house demolitions, crop damage and secondary impacts. However, crop damage is the most reported negative impacts from the interactions. In this article, we reviewed the current situation of humanelephant interactions, extent, and nature of elephants' destruction, the contribution of elephants to ecological restorations and players in rural poverty alleviation. We also provided a conclusion on whether elephants are disastrous pests or agents of ecological restoration. Due to the exceptional anatomical, physiological and behavioural features, people perceive elephants as the most disastrous pests and merciless killers. In a similar way, secondary impacts, such as the unfairness of compensation schemes and intangible conservation benefits, influence negative perceptions and attitudes of people towards elephants.
\end{abstract}

Elephants as agents of ecological restoration provide socio-economic benefits to humans through forest management because the seed dispersal of about 400 species of timber and nontimber forest species depend on the digestive tract of elephants. The livelihoods of about 1 billion poor people in the world depend on forests. On the other hand, elephants are not as destructive as other pests such as rodents, wild boars, and starlings, and they are not as killers as hippopotamus and crocodiles. When the positive and negative impacts of human-elephant interactions are summed up, conservation benefits provided to humans usually exceed conservation costs. The mismanagement of elephants leads to increasing negative impacts, if properly managed; elephants may provide significant contributions to environmental conservation and rural poverty alleviation.

Keywords: Human-elephant conflict; Agricultural pests; Ecological restoration; Asian elephants; Human-wildlife conflict; Endangered species; African elephants

\section{Introduction}

Parker et al. [1] describe the human-elephant conflict as "any interaction which results in adverse effects on human social, economic or cultural life, on elephant conservation or the environment". However, people often confuse HEC with real forms of conflicts; HEC is just the interaction between human and elephant rather than actual conflict [2]. Human-Elephant Interactions (HEI) result in human deaths, elephant deaths, human injuries, elephant injuries, destruction of elephant habitat, secondary impacts and destruction of human property [3]. The most common feature of HEI is crop raiding [3-5].

Coexistence between humans and the elephants has a long history with HEI occurring over the entire evolution of our species [6]. According to Lamarque et al [3] human and elephant have interacted since human started sharing the same habitat with elephants, and Lee and Graham [7] described that HEI started since pre-colonial Africa. The physical presence of wide stone walls surrounding ancient villages in Zimbabwe is one of the several pieces of historical evidence for the existence of HEI in Africa [8]. Human-elephant interactions are mostly widespread in the communities adjacent to protected areas, where agriculture is the primary socio-economic activity, specifically in migratory corridors and the buffer zones [9-12]. In Africa, about 37 countries have reported and documented incidents pertaining HEI $[1,3,5]$.

Geographical, political and climatic features influence occurrences and magnitude of HEC [13]. Protected areas provide inadequate protection to entire ecosystems for elephants because about $80 \%$ of elephant habitats are outside the designated protected areas Lamarque et al.; Muruthi; Sitati et al. [3,14,15], though suitable and wellpreserved habitats exist inside core protected areas [6]. Anthropogenic activities have blocked dispersal routes and genetic migratory corridors that usually provide alternative feeding patterns and an opportunity for exchanging genetic materials $[3,5,16]$.

Conversion of elephant habitats significantly affects elephant foraging preference, feeding patterns and accessibility to other ecological resources $[11,17,18]$. Anthropogenic activities, such as conversion of elephant areas into agriculture, settlements, or infrastructures are the fundamental causes of HEI [6,9]. Also, exponential human population growth amplifies the demand for land, water, food, energy and industrial raw materials, intensifying habitat fragmentation and increased resource competition between human and elephant $[3,5,19,20]$. Fragmented habitats limit elephant movement into small patches or "ecological islands". Compressed and fragmented habitats lack migratory routes which elephants use for 
temporary migration to ecological patches with adequate food, water and breeding mates [1]. Restriction of elephant movements widens the interface of interaction and resource competition between human and elephants [21].

It's hard to manage the situation where humans and elephants compete for the same limited resources Songhurst and Coulson [22], especially in Africa where human population is growing at such a fast rate [3]. Size and structure of human populations usually influence the intensity and frequency of HEI [23]. For instance, as human populations in Tanzania increase so does the blocking of elephant migratory corridors [5]. An abrupt increase in human population in Kenya amplified rapid conversion of natural forests into agricultural fields and human habitation [16]. Increase in the human population in India led to the significant conversion of forests into human settlements [21]. Lee and Graham [7] asserted that rapid increase in human populations and high conversion rate of elephant habitats into other forms are more significant threats to elephants than ivory trade.

Due to the catastrophic elephant damage, local people label elephants as agricultural pests and merciless killers. People sustain extreme damage from elephants in the form of life, property, and crops. The uncompensated and uncontrollable damage from elephants undermine the local population's efforts and desire to participate in elephant conservation. Conservation and land policies hardly balance the needs of human and elephants adequately. As a consequence, elephants become uncontrollable and unprotected outside protected areas because $80 \%$ of elephants, in the countries with viable populations, elephants are found outside protected areas (reference). The elevated high population of elephants outside protected areas increases the magnitude and frequency of elephant damage.

As a consequence, local people label elephants as the most destructive agricultural pests because of the lengthy interactions and disturbances. Under certain circumstance, it is hard to manage elephants because of their two debating representations; local people label elephants as agricultural pests while ecologists recognise Elephants as agents of ecological restorations. In this matter, each conflicting part has strong reasons, beliefs, and experiences upon the stance. In this article, reviewers summarised the existing state of knowledge about elephants as agricultural pests and agents of ecological restorations, and synthesised findings from those publications, by forming articulated arguments, discussion, and conclusion about whether elephants are agricultural pests or agents of ecological restorations. A Proper understanding of societal and environmental stance helps conservationists and local people formulate appropriate plans and policies for sustainable elephant conservation.

\section{Material and Methods}

Reviewers used several publications to obtain crucial information about elephants, agricultural pests, and ecological restorations. In this article, we identified and used basic features of pests as yardsticks for branding any animal as an agricultural pest. In a similar way, reviewers used guiding principles of ecological restorations as benchmarks for labelling any species as an agent of ecological restorations. Before confirming whether elephants are agricultural pests, authors matched the essential features of pests with those of elephants to determine if they match. For comparison purposes, we identified and selected several destructive agricultural pests in the world basing on their damage severity to crops, and fatalities to humans and livestock.
Moreover, we compared elephant damage to crops and property and deaths to people and livestock to the selected disastrous agricultural pests. Before acknowledging whether elephants are the most disastrous pests or not, the magnitude of elephant damage and fatalities were presumed to be more than those from selected disastrous agricultural pests. On the other hand, we used ecological and societal features as benchmarks for scrutinising Elephants as agents of ecological restorations. The guiding principles of ecological restorations were matched to elephants to ascertain their roles in ecological restorations. Their discovered ecological roles were, furthermore, analysed for their contributions to direct and indirect contributions to societal needs.

Before the literature search, the reviewers formulated the following three questions: - are elephants agricultural pests? Are elephants the most disastrous agricultural pests? Do elephants sustain people's livelihoods? The questions provided a guideline for searching relevant publications. Computerised and the non-computerised extensive search was conducted to identify and located relevant publications to answer review questions. To obtain as many publications as possible elephant conservation, pest management, ecology and wildlife databases were extensively searched. Reviewers searched for books, governmental and non-governmental reports, articles and conference proceedings. Google scholar and the web of science were used to search for relevant publications. Due to an inadequate number of relevant publications, reviewers included comparative studies to obtain answers to questions. Relevant studies were selected according to minimum acceptable requirements. The assessment and acceptance criteria based on the relevance and strength of their answers to review questions. Furthermore, the studies were assessed basing on their contribution to theories and knowledge in the areas of elephant damages, ecology, and pest management. Selected studies provided adequate answers to review questions. Due to the complication of summarising research findings from studies with different study design, reviewers opted to summarise some results narratively and few in tables.

The web-based search obtained 50 studies. We used 30 publications to answer three questions. Of which, five publications linked elephants directly to agricultural pests and ten mentioned indirectly elephant as pests. 14 publications provided insights about elephants sustaining forests and people livelihoods, of which 8 provided a definite answer to Elephants as agents of ecological restorations and 7 provided accurate answers to the contribution of elephants to people's livelihood. Furthermore, to provide a relevant response to each guiding question, selected publications were organised into three sections.

\section{Are elephants agricultural pests?}

Commonwealth [24] have explained that any animal that feeds crops, damages buildings, damages stored food, injures people and kills livestock, is the pest. In this context, pests include vertebrates and invertebrates undomesticated animals. However, the mere physical presence of an animal does not make it a pest. It can only become pests following its frequency of occurrences and magnitude of damages [25]. Bandara and Tisdell [26], Mayfield [27], Steffey and Gray [25] outline essential characteristics of the agricultural pest, which include but not limited to suitable habitats, high population, significant damage, expensive control methods and difficultness to control after the impacts. These are important features which most of the pests usually exhibit. Pest may display these features either gradually, routinely and simultaneously. 


\section{Pest should have suitable habitats}

Agricultural pests need sustainable sources of food, shelter and breeding grounds to survive. Places with large quantity and high quality of food, water, and cover become more suitable for pests. For any animal to become pests, its needs must clash with human needs. People nearby protected areas compete with elephants for food, water, and cover. In those areas, people share the same basic needs with elephants $[13,26,28]$.

In that situation, the elephant needs clash with human needs because elephants usually locate high quality and quantity of food, water, and cover outside protected areas. It is the reason $80 \%$ of elephants inhabit areas outside the core protected areas [3]. Likewise, elephants prefer agricultural food crops to wild plants because they are palatable and nutritious with relatively little secondary defensive mechanisms [17]. It is an interspecific competition which elephants usually outweigh humans by damaging crops, life, and property.

\section{High population or breeding rate}

Agricultural pests must have a large population and breeding rate to disturb people. With a large population of pests, the damage to human property and life also increase. Likewise, increase in elephant population heightens the frequency and magnitude of damage to crops and property $[3,5,7]$.

However, it takes only one habitual crop raider to cause significant damage to crops and property because elephants have unique behavioural patterns such as great feeding appetite, lengthy active periods of about 18 hours per day, extensive home ranges and the ability to kill humans and destroy their property [29].

In those situations, when elephant population attains overabundance, crops and properties damage, human deaths and injuries also increase [30].

\section{Significant damage to crops and property}

Under certain condition, agricultural pests should be able to cause significant disturbance to humans. Medical pests cause deaths and injuries, urban pests damage buildings and agricultural pests damage crops. In those categories, elephants are medical, urban and agricultural pests $[3,7,20,31]$.

Because of their significant and uncompensated crop damage, and nuisance, people residing in the boundaries of elephants' ranges consider elephants as agricultural pests [26]. Parker et al. [1] found that elephant damage both stored crops and field crops. Such damages intimidate food security during drought season because of stealing grain from storage facilities [3].

Elephants attack subsistence peasants who are both economically and nutritionally poor Hazarika and Saikia [29], losing crops and family members means increased poverty, health constraints, malnutrition and illiteracy [32].

As medical pests, elephants cause hidden or secondary impacts to people, kill and injure livestock, kill and injure humans [33-36]. Elephants also kill humans and livestock. As urban pests, elephants demolish houses, water taps, water tanks and grain stores [3].

\section{Control methods should be expensive and ineffective}

Economic loss occurs when the costs of controlling pests exceed the crop loss Mayfield, Hill [27,37] described the elephant damage and fatalities as conservation costs, those are significant expenses incurred by people in the form of abandonment of their homes, marriage problems, increased risk of injury from wildlife, and increasing the risk of contaminating diseases such as malaria during the night. Successful control of elephants requires expensive and sophisticated methods.

Traditional methods are cheapest, easy to use but ineffective and dangerous at a high level of the conflict; application of advanced methods such as electric fences becomes unprofitable to farmers [38]. Likewise, using birth contraceptives to reduce overabundant elephants is very costly and slow method [39]. Empirical evidence shows that the expensive and ineffective control methods influence people to label elephants as agricultural pests [26].

\section{Pest should be difficult to control}

Pests are usually difficult to control except by using integrated pest management approach. Likewise, it is hard to control elephants because of their intelligence and rapid adaptability to most traditional methods Fernando et al. [38].

Integration of different conventional methods is difficult because most of the techniques are specific to the area and social and economic scenarios. Similarly, elephants are difficult to control because local people lack devolution of full decision making to control problem elephants, regional planning does not consider human-elephant interactions, many conservation policies, and legislations do not consider human-elephant interactions accordingly [40].

\section{Are elephants the most disastrous agricultural pests in the world?}

For elephants to become the most disastrous agricultural pest, they should be able to perpetrate massive economic damage to crops and property more than other pests. Studies show that elephants cause moderate damage than other agricultural pests (Table 1). Wild pig inflicts the most significant to agriculture than other agricultural pests. In that circumstance, the agricultural damage from African elephants and Asian elephants are lower than rodents, wild pig, European Starling, Red-billed Quelea and desert locus.

However, studies show elephants inflict more extensive crop damage than other agricultural pests. Elephants as generalist pests destroy different types of plants and parts of the crops, including herbs, trees, nuts, fruits, roots, barks, branches and seeds. They are also responsible for pre-harvest and post-harvest damage [3].

On the other hand, for elephants to become the most disastrous agricultural pests, they should be able to cause significant fatalities more than other agricultural pests. Studies indicate that both African elephant and Asian elephant cause lower deaths and injuries to people and livestock than other agricultural pests.

As the comparison, a lion causes the highest number of human and animal facilities. It is, therefore, clear that elephants produce lower fatalities to people and livestock than a Nile crocodile, lion, and Grey Wolf (Table 2). 
Citation: Mamboleo AA, Doscher C, Paterson A (2017) Are Elephants the Most Disastrous Agricultural Pests or the Agents of Ecological

\begin{tabular}{|c|c|c|c|c|c|}
\hline Species & Crop & $\begin{array}{l}\text { Estimation of annual } \\
\text { loss (USD) }\end{array}$ & Estimation method & Region & Reference \\
\hline $\begin{array}{l}\text { Rodents } \\
\text { atalensis) }\end{array}$ & Maize & $4,50,00,000$ & Literature review & Tanzania & Meerburg et al., Stenseth et al. [41,42] \\
\hline Wild pig (Sus scrofa) & Agricultural crops & $1,50,00,00,000$ & Literature review & United States & Burton et al. [34] \\
\hline $\begin{array}{l}\text { African elephant } \\
\text { (Loxodonta africana) }\end{array}$ & $\begin{array}{l}\text { Maize, millet and } \\
\text { sorghum }\end{array}$ & 99,000 & Literature review & Cameroon & Naughton et al. [43] \\
\hline $\begin{array}{l}\text { Asian elephant (Elephas } \\
\text { maximus) }\end{array}$ & Crops and properties & $7,48,248$ & Literature review & Southern India & Gubbi et al. [44] \\
\hline $\begin{array}{l}\text { European } \\
\text { (Sturnus vulgaris) }\end{array}$ & Many crops & $80,00,00,000$ & Literature review & United States & Linz et al. [45] \\
\hline $\begin{array}{l}\text { Red-billed Quelea (Quelea } \\
\text { quelea) }\end{array}$ & Rice & $5,40,00,000$ & Literature review & Sub-Saharan Africa & Otieno et al. [46] \\
\hline $\begin{array}{l}\text { Desert locust } \\
\text { (Schistocerca gregaria) }\end{array}$ & Many crops & $4,50,00,000$ & Literature review & Africa & Thomson and Miers [47] \\
\hline
\end{tabular}

Table 1: Monetary estimates of crop and property damage by agricultural pests.

\begin{tabular}{|l|l|l|l|l|l|}
\hline Major Species & Human deaths & Human injuries & Livestock deaths & Region & Reference \\
\hline $\begin{array}{l}\text { Nile crocodiles (Crocodylus } \\
\text { niloticus) }\end{array}$ & 65 & 45 & 80 & Zambia & Tanzania \\
\hline $\begin{array}{l}\text { African elephant (Loxodonta } \\
\text { africana) }\end{array}$ & 50 & 40 & - & Asian continent \\
\hline $\begin{array}{l}\text { Asian elephant (Elephas } \\
\text { maximus) }\end{array}$ & 226 & 56 & 50 & 99 & Tanzania \\
\hline $\begin{array}{l}\text { Lion (Panthera leo) } \\
\text { Grey wolf (Canis lupus) }\end{array}$ & 76 & 40 & 89 & Doyle et al. [48] & India \\
\hline
\end{tabular}

Table 2: Estimates of annual fatalities by agricultural pests worldwide.

\section{Are elephants the agents of ecological restoration?}

Ecological restorations mean repairing and re-establishment of the functions, structures, and integrity of ecosystems that have been previously damaged by anthropogenic and non- anthropogenic activities while sustaining people's livelihoods. Ecological restoration is a broad concept in ecology, as a matter of specification; studies have revealed that elephants play a part in ecological restorations through ecosystem remediation. As a consequence, forest ecosystem restoration redistributes vanished and impaired ecosystem services to humans and wildlife species. Wong [53] suggested that a successful activity of ecological restoration should be efficient, effective and engaging. The guiding principles, "triple $E$ " stand as the guidelines for undertaking and evaluating environmental restoration process.

\section{Is an ecological restoration by elephants effective?}

Elephants restore ecosystem structures, functions, compositions and dynamics while supporting the availability of ecosystem components, cultural resources, and socioeconomic conditions. Elephants restructure biophysical environment of a particular ecosystem. As results, ecologists brand elephants as "ecosystem engineers" Pringle [54], "keystone species" Hoare and Du Toit [55], "flagship species" and "landscape species" [56,57]. Each name symbolises the specific roles and contributions elephants make to forest ecosystems. CamposArceiz and Blake [58] branded elephants as mega-gardeners of the forest because of their ecological roles in dispersing forest seeds before germination. Similarly, due to their capabilities of manipulating the availability of ecological resources for other organisms through modification of natural environment, conservationists brand elephant's ecosystem engineers [54].

As examples, elephants facilitate other herbivores by opening up thick vegetation [59]. Elephants are keystone species because they have a unique role to play in ecological rehabilitation [30]. Massive body structure enables elephants to restore or engineer habitats for other animals to use [60]. In the case of effectiveness, elephants are agents of ecological conservation because of their natural and physical abilities to provide myriads of the environmental need to humans and other species of wildlife (Table 3 ). 


\begin{tabular}{|c|c|c|c|}
\hline Ecological process & Ecological importance & Beneficiaries & Reference \\
\hline Habitat rehabilitation & $\begin{array}{l}\text { Reduced tree height and tree species results in the formation of new trees and } \\
\text { fresh leaves that become available to other species. Clear-cut areas help other } \\
\text { species detect predators easily }\end{array}$ & $\begin{array}{l}\text { Elephants, people and } \\
\text { wild animals }\end{array}$ & $\begin{array}{l}\text { Gough and Graham, } \\
\text { pringle }[56,60]\end{array}$ \\
\hline Frugivorous & $\begin{array}{l}\text { Elephants consume fruits and defecate seeds which are either eaten by other } \\
\text { animals or germinate }\end{array}$ & $\begin{array}{l}\text { Birds, primates, } \\
\text { mammals and insects }\end{array}$ & $\begin{array}{l}\text { Campos-Arceiz and Blake } \\
\text { [58] }\end{array}$ \\
\hline Seed dispersal & $\begin{array}{l}\text { Elephants play a significant role as an agent of seed dispersal by consuming large } \\
\text { quantities of fruits and defecating intact seed }\end{array}$ & $\begin{array}{l}\text { Forests, birds, primates } \\
\text { and insects }\end{array}$ & Baskaran and Desai [61] \\
\hline $\begin{array}{l}\text { Geophagy and soil } \\
\text { excavation }\end{array}$ & $\begin{array}{l}\text { Elephants excavate water and rocks with a high quantity of different minerals for } \\
\text { detoxication and mineral supplement. Elephants and other species consume the } \\
\text { hydro-mineral and soil }\end{array}$ & $\begin{array}{l}\text { Elephants, other species, } \\
\text { and livestock }\end{array}$ & $\begin{array}{l}\text { Houston et al., Sienne et } \\
\text { al. }[62,63]\end{array}$ \\
\hline $\begin{array}{l}\text { Facilitating } \\
\text { germination }\end{array}$ & $\begin{array}{l}\text { Undigested seeds passing through the digestive track of elephants have high } \\
\text { germination probability. Elephant dung promotes germination of seedlings by } \\
\text { providing the adequate nutritive environment }\end{array}$ & $\begin{array}{l}\text { Forests, people, birds, } \\
\text { mammals, and insects }\end{array}$ & Baskaran and Desai [61] \\
\hline Production of dung & $\begin{array}{l}\text { Elephants excrete a large amount of manure, which supply nutrients for plants, } \\
\text { cover for invertebrates and food to other organisms. Excrement from elephants } \\
\text { contains seeds, fruits, leaves, minerals, barks and grasses which make it highly } \\
\text { necessary for germinating trees }\end{array}$ & $\begin{array}{l}\text { Forests, people, birds, } \\
\text { mammals, invertebrates } \\
\text { and insects }\end{array}$ & $\begin{array}{l}\text { Campos-Arceiz and Blake; } \\
\text { Pringle; Van de Koppel et } \\
\text { al. }[54,58,59]\end{array}$ \\
\hline
\end{tabular}

Table 3: Roles of elephants as agents of ecological restoration.

\section{Is an ecological restoration by elephants efficient?}

Elephants perform productive ecosystem rehabilitation activities, in timely and consistently manner, because of their high level of intelligence and behaviours. The ecological restoration by elephants affects the ecosystem species, communities and institutions levels. Such ecological restoration requires minimum human intervention because the process occurs naturally. As an example, seed dispersals and germinations by elephants coincide with particular seasons of the year, and places. However, the minimum human intervention through elephant management is necessary to maintain the long-term capacity of elephants in ecosystem maintenance. In the case of cost effectiveness, since humans have slight interference in restoration, the associated costs are low to conservation agencies but relatively high to farmers in the neighbouring areas.

\section{Is an ecological restoration by elephants engaging?}

The ecosystem remediation is consistently engaging due to anthropogenic and environmental considerations. The restoration provides an opportunity for people to reconnect with nature and culture because it values restructures cultural forests and attractions, and places, it assists in enhancing communities livelihoods through the provision of timber and non-timber forest products, and employment opportunities. The ecosystem restoration is significant because it provides humans, livestock and other wildlife species a chance to reuse the damaged ecosystem services.

\section{Do elephants sustain people's livelihoods?}

Elephants have provided humans with food and shelter, fertilisers and fibres to a human for many years [64,65]. Moreover, elephants provide meat, ivory, traditional medicines and workforce to humans [7]. As examples, people in northern Tanzania declared using elephant parts for medicinal, ceremonial, food and ritual or commercial purposes, especially fat, bones, ears, amniotic fluid, liver and skin for medication [66]. WWF [67] asserted that the people had worshipped Asian elephants for centuries because the animals embrace a fundamental position in cultural depictions to some Asian countries. As an example, in Sri Lanka, the Asian elephant is considered as a foundation for Buddhism and Hinduism [68]. The African elephant attracts tourists to African countries (Table 4) [32].

\begin{tabular}{|l|l|l|}
\hline Socio-economic value & Specific contribution & Reference \\
\hline Religion & Buddhism and Hinduism consider Asian elephants as the centre of their religious affiliations. & Fernando et al. [68] \\
\hline Medication & $\begin{array}{l}\text { People use elephant parts, dung amniotic fluids, placenta, liver, bones, ear, skin, bones, and } \\
\text { fat for medicines. }\end{array}$ & Kioko et al. [66] \\
\hline Food supply & Elephants provide humans with food and shelter. & $\begin{array}{l}\text { Kioko et al., Lee and Graham } \\
{[7,66]}\end{array}$ \\
\hline Source of organic fertiliser & Provision of fertilisers and workforce to farmers & Lee and Graham [7] \\
\hline Employment & $\begin{array}{l}\text { Provision of direct and indirect employment to people through ecotourism and forest } \\
\text { management. }\end{array}$ & FAO [69,70] \\
\hline Ecotourism & $\begin{array}{l}\text { Provision of foreign currencies, the annual value of one elephant is 44,554,844.47 USD in } \\
\text { ecotourism. }\end{array}$ & Desai [71] \\
\hline
\end{tabular}

Table 4: Roles of elephants in socio-economic development. 


\section{Discussion}

Labelling elephants as agricultural pests or conservation agents of ecological restoration require a clear understanding of the magnitude of elephant damage and facilities to human and specific roles elephants contribute to ecosystem restoration. Studies have proved that elephants are agricultural pests because of their significant damage to crops and property, difficultness to control, expensive and ineffective control techniques, and interspecific competition with humans for food, space, and water. Elephant perpetrates damage to human property and crops unselectively; they destroy infrastructure, food crops, and cash crops. Moreover, elephants are capable of raiding different types of plants and consuming different structural parts of the plant from roots to leaves, which make them the generalist agricultural pests. Elephants feed on seeds, bark, fruits, leaves, grasses and trees. Also, elephants cause damage to both pre-harvest and post-harvest crops. However, elephants are not the most disastrous agricultural pests because their damage to human properties and life are relatively lower than other agricultural pests. Species like rodents, wild pigs, and Red-billed Quelea inflict more damage to crops than elephants. Similarly, lions, crocodiles, and Grey wolves cause more fatalities to human and livestock than elephants.

In fact, elephants cause relatively insignificant damage to subsistence farmers [3]. Regardless of relatively low damage and fatalities, people unfairly rank elephants as the most disastrous, Hoare [36] explained that elephants are not routine crop raiders but their damage to the plant are more localised and severe that those of other pests. The nature and magnitude of elephant damage usually determine people's perceptions and attitudes towards elephants. The degree of pain resulting from elephant damage differs among people, depending on their socio-economic activities and geographical locations. For example, crop damage is more traumatic to peasants because it means food insecurity but also malnutrition, delayed school attendance for children and poor access to medication. Furthermore, cultural complexity may influence people perceptions on elephants. Some cultures do not regard elephants as normal creatures, for example. It is possible for residents to tolerate the substantial agricultural damage from livestock and yet impossible to endure comparatively minor crops damage from an elephant [72]. Besides, in certain localities in Burkina Faso, people are more tolerant if the human death is caused by a crocodile than an elephant [3]. Despite relatively small damage from elephants, people still regard elephants as ruthless killers and pests.

Nevertheless, human deaths, house demolitions, and crop damage are not the main determinants of people's perceptions towards elephants but hidden impacts. These are the secondary effects, which influence attitudes of people towards elephants $[1,33]$. Secondary or hidden effects are also called "socio-economic opportunity costs" [1]. These are the state of psycho-social well-being emanating from the conflict [33]. The effects include fear of injury or death, restriction on human movement (particularly at night), competition for water resources. Others are poor nutrition status, competition for livestock grazing ground, reduced school attendance for children due to fear of elephants, disruption of families because of marriage problems $[1,33]$. The size of the animal, the extent to which the animal is considered dangerous nocturnal and easiest method for a human to control the animal influences the perceptions towards animal species [72].
Moreover, the absence of an efficient mechanism to interpret hidden impacts into an economic scale hinders conflict mitigation measures [1]. Likewise, conservation policies and laws have also disregarded hidden implications as claimable impacts [4].

Human occupations in elephant habitats, increased human population, isolation of the crop field, proximity to protected areas and percentage of cultivation increase the frequency and magnitude of elephant damage and fatalities [1,22]. The loss is prominent in communities residing adjacent to protected areas, buffer zones and corridors $[9,12]$. In that case, people occupying areas adjacent to protected are more likely to perceive elephants as the most disastrous agricultural pests than urban people due to frequent and severe damage and fatalities from elephants. Lack of landscape and regional planning which integrate the needs of elephants and local people makes elephants overwhelming. As a consequence, people develop uncertainty about geographical boundaries and descriptions of protected areas, corridors, buffer zones, dispersal areas, refugia, migratory areas and breeding areas. Integrated land use plan may lead to a proper understanding of natural elephant ranges and promote sustainable human settlements to reduce frequent interactions with elephants $[73,74]$.

The main conservation agenda of many conservation agents is elephant protection inside protected areas while overlooking humanelephant interactions outside protected areas [30,67]. Human-elephant interaction ranks second to ivory trade as a major threat to the existence of elephants [30]. However, many conservation organisations, in developing countries, claim to lack adequate resources, personnel and even legal authority, to control elephants outside reserves. Likewise, local people require devolution of full decision making to control problem elephants in their localities. A lack of a systematic procedure and legal authority to directly deal with problem elephants influences people to perceive elephants as an uncontrollable agricultural pest [17]. As a response, people use lethal methods to control problem elephants [12]. Sometimes people respond to elephant threats by killing them and eradicating their native habitats to prevent further damage. For example, $79 \%$ of individuals at Koija in Kenya recommended elephant killing in retaliation for a human death [16]. Some governments authorise elephant killings as a consolation to the sufferers of HEC, such as the Kenya Wildlife Authority which killed between 50 to 120 problem elephants each year in retaliation for human deaths [3]. It is worth noting that, retaliatory killing of elephants takes place without a precise knowledge of which elephant caused the problem Lamarque et al., Madden [3,4] recommend that conservationists should be careful about the prescription of mitigation measures because each situation of HEI has unique integration of social, cultural, economic, political, historical, species and geographic complications. Unfortunately, most conservationists are trained in ecological perspectives with either little or inappropriate knowledge on social sciences [12]. Under certain circumstance, their conflict mediation skills become harder to cope with social structures and social dynamics that tend to be overwhelming [74]. 
Conflict mediation expertise and approaches may influence people's perceptions on elephants. Shifting from conventional to communitycentred conservation methods creates a sense of ownership of both conservation costs and profits [75]. People tend to experience conservation costs in forms of life and property losses. Many governments have adopted community-centred conservation approaches. However, people contempt to participate because of their ineffectiveness and uncertainty on cost-profit sharing mechanisms, which are either lacking or inappropriate [3]. If properly communicated and executed, cost-profit sharing mechanism of elephant conservation may instil a sense of elephant 'ownership', empowerment and responsibilities to local people. Currently, households hardly acquire direct, tangible benefits from conservation agencies. When local conservation institutions and residents are duly empowered to deal with problem animals, they become supportive and responsible about conservation [4]. Some governments have commissioned wildlife consolation and insurance schemes to compensate people against life and property losses from elephants. However, people complain about the schemes unfairness of and biases. And, also their inabilities to process the claims within a reasonable time. As results, people have biased perceptions towards elephant conservation, for example, $52 \%$ of individuals around Bénoué National Park in Cameroon recommended eradication of elephants from the park to reverse the trend of crop damage [9]. Rural people killed 15 elephants as retaliation for crop damage in Kilimanjaro region between 1996 and 1997, and residents speared to death 141 elephants in Amboseli ecosystem between 1971 and 1990 [14].

The human component is the leading cause of many environmentalrelated problems including human-elephant interactions Bandara and Tisdell [76], poaching Blanc et al. [13] and deforestations FAO [70]. As consequences, human actions and decisions in environment results into the disappearance of essential ecosystem services and forest species. Ecological restoration by elephants is one of the potential measures for restoring the vanished ecosystem services. Elephants as agents of ecological restorations, manipulate habitats into various forms. As engineers of the ecosystem, elephants transform different vegetation covers to provide habitat, food, water and pathways to wildlife species and domesticated animals. Through habitat transformation, wildlife species get fresh food and covers; humans get medicines, firewood, and forest products. It also provides clear visibility for preys to detect predators. Likewise, soil excavation by elephants provides food, water and mineral supplements to different wildlife species. In the dry season, elephants excavate soil to uncover hydro-mineral, which may also become available to wildlife species and livestock as mineral supplements and for detoxification. The elephant dung is likewise important to wildlife species. Some birds and insects use elephant dung as their habitats and food. In the case of socio-economic benefits, elephants provide direct and indirect benefits to humans. Elephants provide people directly with food and products. Through sustainable forest management, elephants manage tropical forests for climate, products, environmental services, conservation of another biodiversity, provision of cultural services, livelihood support and poverty alleviation. Elephants are important agents for the functioning of forest ecosystems as they maintain forest species diversity and low redundancy in seed dispersal systems [58]. The abilities of elephants to retain seeds in the digestive gut in a long time facilitate seed dispersal process over a long distance from a parent tree [61]. Elimination of elephants from tropical forests may cause severe impacts on forest species that depend on their seed dispersal capabilities [77]. In that case, the demographic process of about 451 species of plants in tropical forests depends on elephants for seed dispersal [58]. The tropical forests supply timber and non-timber forest products to local people in forms of fruits, mushrooms, vegetable, medicines and firewood to mention few. In the case of ecological and societal values, elephants through forest management provide support to nearly one billion people living in extreme poverty and employment to 100 million people worldwide [70].

\section{Conclusion}

Before confirming whether elephants are pests or agent of ecological restorations, it is important to have a proper understanding of the features that make an animal a pest or agent of ecological restoration. Similarly, features that distinguish agricultural pests and agents of ecological restorations. In the case of whether elephants are pests or not, studies show that elephants are agricultural pests, medical pests, and urban pests because they fit in with all essential features and categories of pests. Geographical location of elephant damage and fatalities, typology and magnitude of elephant damage, the high cost of controlling elephants, ineffective control techniques, and interspecific competition with humans make elephants agricultural pests. Despite their damage and fatalities, elephants are not the most disastrous agricultural pests in global, continental, regional and country perspectives. Elephant damage and deaths are more localised [8]. Elephants are not as destructive as a lion and Nile crocodiles to livestock and are not as destructive to as European Starling and Redbilled Quelea to crops. In those situations, elephants are not the most disastrous agricultural pests because their damage and fatalities are relatively lower than many disastrous agricultural pests. On the other hand, elephants are agents of ecological restoration because of their capability in redistributing damaged ecosystem services to human, livestock, and other wildlife species. Through sustainable forest management, elephants provide direct and indirect basic ecological and societal needs for local people and wildlife species. Moreover, elephants encompass effective, efficiency and engaging as guiding principles for in ecological restoration. Elephants have provided human with meat, ivory, traditional medicines and workforce for centuries [7]. It a clear evidence that human and herbivores have coexisted over an extended period, the relationship between humans and herbivores deteriorated after human increased dependence on domesticated herbivores, and encroached on elephant's natural habitats [64]. In short, when positive and negative factors of elephant conservation are summed up, the conservation benefits that elephants provide to humans usually outweigh the conservation costs [74]. Despite associated conservation benefits that human obtain from elephants, humans have unfairly managed elephants. Hidden impacts, the unfairness of compensation and consolation schemes, incapability to control problem elephants, intangible conservation benefits at the household level are likely to influence the perceptions and attitudes of people towards the ferocity of elephants. On this note, societal values of elephants to people are either unknown or outweighed by secondary impacts of human-elephant interactions. Moreover, difficulty in balancing human and elephant needs determine the complexity of reducing elephant damage and fatalities. Likewise, inappropriate decisions and actions from human component increase the difficulty of the problem. As part of the solution, properly designed and precisely executed landscape and region plans may result in successful elephant management inside and outside protected areas. Sustainable elephant management may lead into disregarding elephants as agricultural pests 
and promote sustainable environment conservation, which is essential for sustainable rural development.

\section{Acknowledgement and Funding}

New Zealand Development Scholarship Program supported financial and logistical support. However, we wholeheartedly appreciate Saint Augustine University of Tanzania (SAUT), Lincoln University (LU), Tanzania National Parks (TANAPA), Bunda District Council, Ministry of Natural Resources and Tourism of Tanzania for making the study technically possible.

\section{Statement of Competing Interests}

All authors have carefully read and understood the journal policy; therefore we declare that we had support from New Zealand Development Scholarship (NZDS), no financial and logistical support with political, apolitical, governmental and non-governmental organizations that might have interest in the submitted manuscript. We also confirm that all authors do not have any competing interest in the submitted work.

\section{Authors' Contribution}

We solemnly declare that this research has neither been submitted for consideration nor published elsewhere. We confirm that all authors have contributed substantially to this work, and all responsible organizations which technically and logistically contributed to this study have authorized its publication.

\section{Key Message}

Elephants are agricultural pests due to the infliction of economic damage to crops and property. Moreover, the pachyderm with humans for food and space and controlling of elephants is hard and dangerous. Elephants perpetrate more significant damage at local than at national, regional and continental levels. As a consequence, elephant damage becomes less disastrous than damages from other agricultural pests such as a wild boar, Starling, Red-billed Quelea and lion. Despite the loss, elephants remain as the key ecological species, with unique capabilities of revitalising essential ecosystem services to people and other wildlife species. It is hard to conserve a wildlife species with two incompatible images; residents brand elephants as the most destructive agricultural pests while conservationists label the animals as agents of ecosystem rehabilitation. It is important to understand that the benefits of elephants exceed their damage because elephants make the invaluable contributions to society needs and environmental sustainability.

\section{References}

1. Parker GE, Osborn FV, Hoare RE, Niskanen LS (2007) Human-elephant conflict mitigation: a training course for community-based approaches in Africa (participants' manual) Nairobi, Kenya: IUCN.

2. Peterson MN, Birckhead JL, Leong K, Peterson MJ, Peterson TR (2010) Rearticulating the myth of human-wildlife conflict. Conservation Letters 3: 74-82.

3. Lamarque F, Anderson J, Fergusson R, Lagrange M, Osei Owusu Y, et al. (2009) Human-Wildlife Conflict in Africa: Causes, Consequences and Strategies. Food and Agriculture Organisation, Rome, Italy 1: 157.

4. Madden F (2004) Creating coexistence between humans and wildlife: global perspectives on local efforts to address human-wildlife conflict. Human Dimensions of Wildlife 9: 247-257.
5. Mduma SR, Lobora AL, Foley C, Jones T (2010) Tanzania Elephant Management Plan 2010-2015.

6. Ladan SI (2014) Examining human wildlife conflict in Africa. International Conference on Biological, Civil and Environmental Engineering, Dubai, UAE.

7. Lee PC, Graham MD (2006) African elephants Loxodonta africana and human-elephant interactions: implications for conservation. International Zoo Yearbook 40: 9-19.

8. Hoare RE (1999) Determinats of Human elephant conflicts in land-use mosaic. J Appl Ecol 36: 689-700.

9. Granados A (2011) Local attitudes and elephant spatial distribution in the Bénoué region, Cameroon: implications for human-elephant conflict and conservation. Concordia University, Montreal, Canada.

10. Le Bell S, Murwira M, Mukamuri B, Czudek R, Taylor R, et al. (2011) Human-wildlife conflict in Southern Africa: Riding the whirl wind in Zimbabwe and in Mozambique.

11. Leel PD, Graham MD, Douglass H, Adams WM (2009) The movement of African elephants in human-dominated land-use mosaic. Animal Conservation 12: 445-455.

12. Treves A (2007) Balancing the needs of people and wildlife: When Wildlife Damage Crops and Prey on Livestock. University of WisconsinMadison, USA.

13. Blanc JJ, Barnes RFW, Craig GC, Dublin HC, Thouless CR, et al. (2007) African Elephant Status Report 2007: An update from the African Elephant Database. Gland, Switzerland: International Union for Conservation of Nature.

14. Muruthi P (2005) Human Wildlife Conflict: Lesson learnt from AWF's African heartlands. African Wildlife Foundation. Arusha, Tanzania.

15. Sitati NW, Walpole MJ, Lwaderi WN (2005) Factors affecting susceptibility of farms to crop raiding by African elephants: using a predictive model to mitigate conflict. J Appl Ecol 42: 1175-1182.

16. Okello MM, D’amour DE (2008) Agricultural expansion within Kimana electric fences and implications for natural resource conservation around Amboseli National Park, Kenya. J Arid Env 72: 2179-2192.

17. Knight J (2000) Natural Enemies: People Wildlife Conflicts in Anthropological Perspective. New York, USA: Psychology Press.

18. Mutanga O, Adjorlolo C (2008) Assessing the Spatial Patterns of Crop Damage by HEC. Alternation 15: 222-239.

19. Kioko J, Zink E, Sawdy M, Kiffner C (2013) Elephant (Loxodonta africana) demography and behaviour in the Tarangire-Manyara Ecosystem, Tanzania. South African J Wildlife Res 43: 44-51.

20. Osborn FV (2004) Seasonal variation of feeding patterns and food selection by crop-raiding elephants in Zimbabwe. Afr J Ecol 42: 322-327.

21. Rahman S, Rahman SM, Motaleb MA, Sobhan I, Khan NA (2010) Geospatial techniques and route and corridor mapping of Asian elephants: a participatory initiative for conservation. International Union for Conservation of Nature, Bangladesh.

22. Songhurst A, Coulson $\mathrm{T}$ (2014) Exploring the effects of spatial autocorrelation when identifying key drivers of wildlife crop-raiding. Ecol Evol 4: 582-593.

23. Sitati NW, Walpole NJ, Smith RJ, Leader WN (2003) Predicting spatial aspects of human-elephant conflic. J Appl Ecol 40: 667-677.

24. Commonwealth (2010) Environmental health practitioner manual: a resource manual for environmental health practitioners working with Aboriginal and Torres Strait Islander Communities (ISBN: 978-1-74241-132-3). Australia: Commonwealth of Australia.

25. Steffey K, Gray M (2016) Managing Insect Pests. In Illnois Agronomy Handbook Illnois, US: College of Agricultural, Consumer and Environmental Sciences p: 224.

26. Bandara R, Tisdell C (2002a) Asian elephants as agricultural pests: damages, economics of control and compensation in Sri Lanka. School of Economics. University of Queensland. Brisbane, Australia.

27. Mayfield K (2015) What constitutes a pest?

28. Ebregt A, Greve P (2000) Buffer zones and their managements: policy and best practices for terrestrial prectices in developing countries. 
Wageningen, the Netherlands: National Reference Centre for Nature Management.

29. Hazarika R, Saikia A (2013) The pachyderm and the pixel: an assessment of elephant habitat suitability in Sonitpur, India. Int J Rem Sen 34: 5317-5330.

30. Graham MD, Notter B, Adams WM, Lee PC, Ochieng TN (2010) Patterns of crop-raiding by elephants, Loxodonta africana, in Laikipia, Kenya, and the management of human-elephant conflict. Systematics and Biodiversity 8: 435-445.

31. Naughton TL (1998) Predicting Patterns of Crop Damage by Wildlife around Kibale National Park, Uganda. Conservation Biology 12: 156-168.

32. Gadd ME (2005) Conservation outside of parks: attitudes of local people in Laikipia, Kenya. Environmental Conservation 32: 50-63.

33. Barua M (2014) Circulating elephants: unpacking the geographies of a cosmopolitan animal. Transactions of the Institute of British Geographers 39: 559-573.

34. Burton JL, Westervelt JD, Ditchkoff S (2013) Simulation of Wild Pig Control via Hunting and Contraceptives. US: US Army Corps of Engineers.

35. Chomba C, Senzota R, Chabwela H, Mwitwa J, Nyirenda V (2012) Patterns of human- wildlife conflicts in Zambia, causes, consequences and management responses. J Ecol Nat Env 4: 303-313.

36. Parker RE (2007) Data collection and analysis protocol for humanelephant conflict situation in Africa. Arusha, Tanzania: IUCN.

37. Hill CM (2004) Farmers' perspectives of conflict at the wildlifeagriculture boundary: Some lessons learned from African subsistence farmers. Human Dimensions of Wildlife 9: 279-286.

38. Fernando P, Kumar A, Williams AC, Wikramanayake E, Aziz T, et al. (2008) Review of Human-Elephant Conflict Mitigation Measures Practiced in South Asia: World Wide Fund for Nature.

39. Whyte I, Aarde R, Pimm SL (1998) Managing the elephants of Kruger National Park. Animal Conservation 1998: 77-83.

40. Kube R, Montanye D (2008) Common Ground: solutions for reducing the human, economic and conservation costs of human wildlife conflict. Gland, Switzerland: WWF.

41. Meerburg BG, Singleton GR, Leirsc H (2008) The year of the rat ends: time to fight hunger. Pest Managanament Science 65: 351-352.

42. Stenseth NC, Leirs H, Skonhoft A, Davis SA, Pech RP, et al. (2003) Mice rats, and people: the bio-economics of agricultural rodent pests. Front Ecol Environ 1: 367-375.

43. Naughton L, Rose R, Treves A (1999) The social dimensions of humanelephant conflict in Africa: A literature review and case studies from Uganda and Cameroon. Glands, Switzerland: IUCN.

44. Gubbi S, Swaminath MH, Poornesha HC, Bhat R, Raghunath R (2014) An elephantine challenge: human-elephant conflict distribution in the largest Asian elephant population, southern India. Biodiversity Conservation 2014: 633-647.

45. Linz GM, Horman HJ, Gaukler SM, Penry LB, Bleier WJ (2007) European starlings: a review of invansive species with far-reaching impacts. In W. C. P. G. W. Witmer, K. A. Fagerstone (Chair), National Wildlife Research Center. Symposium conducted at the meeting of the Managing Vertebrate Invasive Species: Proceedings of an International Symposium, United States.

46. Otieno NE, Mutati AS, Akoth C, Chesire D, Ogwang DO, et al. (2015) Economic valuation of rice crop damage by Red-billed quelea and other granivorous birds on a rural irrigation scheme in western Kenya. J Agri Ecol Res Int 2: 156-167.

47. Thomson A, Miers H (2002) Assessment of socio-economic impacts of desert locusts and their control. UK: Department for International Development.

48. Doyle S, Groo M, Sampson C, Songer M, Jones M, et al. (2010) Humanelephant conflict-what can we learn from news? Gajah 32: 14-20.

49. Chardonnet P, Soto B, Fritz F, Crosmary W, Drouet HN, et al. (2010) Managing the Conflicts between People and Lion. \& F. a. A. Organization
(Vol. Ed.). Review and insights from the literature and field experience. Rome, Italy: Food and Agriculture Organization.

50. Kissui BM (2008) Livestock predation by lions, leopards, spotted hyenas, and their vulnerability to retaliatory killing in the Maasai steppe, Tanzania. Animal Conservation p: 1-11.

51. Packer C, Ikanda D, Kissui B, Kushnir H (2006) The ecology of maneating lions in Tanzania. Nature \& Faune 21: 10-15.

52. Suryawanshi KR, Bhatnagar YV, Redpath S, Mishra C (2013) People, predators and perceptions: patterns of livestock depredation by snow leopards and wolves. Journal of Applied Ecology 50: 550-560.

53. Wong M (2007) Principles and guidelines for ecological restorations in Canada's protected areas. Quebec, Canada: National Parks Directorate.

54. Pringle RM (2008) Elephants as agents of habitat creation for small vertebrates at the patch scale. Ecology 89: 26-33.

55. Hoare RE, Du Toit JT (1978) Coexistance between people and elephants in African savannas. Conservation Biology 13: 633-639.

56. Barua M, Tamuly J, Ahmed A (2010) Mutiny or clear sailing? Examining the role of the Asian elephant as a flagship species. Human Dimensions of Wildlife 15: 145-160.

57. Clucas B, McHugh K, Caro T (2008) Flagship species on covers of US conservation and nature magazines. Biodiversity Conservation 17: 1517-1528.

58. Campos AA, Blake S (2011) Megagardeners of the forest e the role of elephants in seed dispersal Acta Oecologica 37: 542-553.

59. Van de Koppel J, Rietkerk M, Van Langevelde F, Kumar L, Klausmeier CA, et al. (2002). Spatial heterogeneity and irreversible vegetation change in semiarid grazing systems. Ame Nat 159: 209-218.

60. Gough KF, Graham IHK (2006) Demography and population dynamics in the elephants Loxodonta africana of Addo Elephant National Park, South Africa: is there evidence of density dependent regulation?. Oryx 40: 434-431.

61. Baskaran N, Desai AA (2013) Frugivory and seed dispersal by the Asian elephants Elephas maximus in tropical forests of Nilgiri Biosphere Reserve, Souther India. Journal of Threatend Taxa 5: 4893-4897.

62. Houston DC, Gilardi JD, Hall AJ (2001) Soil consumption by Elephants might help to minimize the toxic effects of plant secondary compounds in forest browse. Mammal Review 31: 249-254.

63. Sienne JM, Buchwald R, Wittemyer G (2014) Differentiation in mineral constituents in elephant selected versus unselected water and soil resources at Central African bais. Eurpoean Journal of Wildlife Resources 60: $377-382$.

64. Gordon IJ (2009) What is the future for wild, large herbivores in humanmodified agricultural landscapes?. Wildlife Biology 15: 1-9.

65. Woodrofe S, Thirgood F, Robinowitz A (2005) People and Wildife: Conflict or Coexistance. New York, US: Cambridge University Press.

66. Kioko J, Kiffner C, Ndibalema V, Hartnett E, Seefeld C (2014) Maasi people and elephants: values and perceptions. Indian Journal of Traditional Knowledge 1: 13-19.

67. WWF (2004) WWF factsheet about African elephant (Loxodonta africana). In CITES (Chair), CITES. Symposium conducted at the meeting of the Conference of the Parties to CITES, Bangkok.

68. Fernando P, Jayewerden P, Prasad T, Hendavitharana W, Pastorini J (2011) Current status of asian elephants in Sri Lanka. Gajah 35: 93-103.

69. FAO (2010) Global Forest Resource Assessment. Food and Agriculture Oraganisation of the United Nations, Rome, Italy.

70. FAO (2012) Forests and Climate Change. Food and Agriculture Organisation, Rome, Italy.

71. Desai AA (2014) Dead or alive? Valueing an elephant. Surrey. United Kingdom: The David Sheldrick Wildlife Trust.

72. Hill CM (1997) Crop-raiding by wild vertebrates: The farmer's perspective in an agricultural community in western Uganda. International Journal of Pest Management 43: 77-84.

73. Desai AA, Riddle HS (2015) Human-elephant conflict in Asia. U.S. Fish and Wildlife Service Asian Elephant Support. Indonesia. 
Citation: Mamboleo AA, Doscher C, Paterson A (2017) Are Elephants the Most Disastrous Agricultural Pests or the Agents of Ecological Restorations? J Biodivers Endanger Species 5: 185. doi:10.4172/2332-2543.1000185

Page 10 of 10

74. Messmer TA (2000) The emergence of human-wildlife conflict management: turning challenges into opportunities. International Biodeterioration \& Biodegradation 45: 97-102.

75. Kideghesho JR, Mtoni PE (2008) The potentials for co-management approaches in western Serengeti, Tanzania. Tropical Conservation Science 1: 334-358.
76. Bandara R, Tisdell C (2002b) Asian Elephants as Agricultural Pests: Damages, Economics of Control and Compensation in Sri Lanka.

77. Campos AA, Traeholt C, Jaffar R, Santamaria L, Corrlet RT (2012) Asian tapirs are no elephants when it comes to seed dispersal. Biotropica 44: 220-227. 